\title{
Obituary
}

\section{T. G. B. Osborn}

Theodore George Bentley Osborn, Professor Emeritus of Oxford and Adelaide Universities, was born on October 2,1887 . He was educated at Burnley Grammar School and the University of Manchester. His early research was on the fungi and was done mainly during the period 1908-1912, when he was Lecturer in Economic Botany in the University of Manchester. In 1912 he was invited to become Professor of Botany in the University of Adelaide and Consulting Botanist to the Government of South Australia. Shortly before going to Australia, he had married Edith May Kershaw, who was also a botanist and associated with the work of the Botany Department in Adelaide. They had three sons, Peter, Andrew and Richard, all of whom served in World War II; Andrew, an RAF pilot, was killed in action.

When he established the Department of Botany at Adelaide in 1912 Osborn was only twenty-five years old and youthful in appearance. He was fond of the story of how he went into the examination hall, which was being supervised by a middle-aged woman who had not met him, and asked for the Botany I paper. She brought him the paper, and when he said, "And while I'm here I'll have a look at the Agricultural Botany paper, too," she replied, "You'll do nothing of the sort ; you'll just sit down there and get on with your Botany I".

Osborn recognized the need for establishing plant ecology in Australia, and began the work on the ecology of South Australia for which he was well known. $\mathrm{He}$ occasionally undertook other work such as the descriptions of the morphology of Isoetes and Phylloglossum. In collaboration with Professor R. S. Adamson (University of Capetown) he published on the ecology of the Ooldea district in 1922 and on the ecology of the Mount Lofty Ranges in 1924. One of his most important contributions was the establishment, in 1924, of the Koonamore Vegetation Reserve, which is now the oldest biological station in Australia with continuous records. The first and important work on grazing of natural vegetation in arid regions resulted from the collaborative work of Osborn, Wood and Paltridge in this area.

In 1928, Osborn became Professor of Botany at the University of Sydney and he set about reorganizing the undergraduate courses there. He himself took the first year lectures and plant physiology, as well as ecology. At first he continued to clear up his research arising from the work in arid zones but increasingly he became interested in the vegetation of coastal New South Wales. In 1930 he gave the Livingstone Lectures entitled Plant Life in the Sydney District, with an ecological approach. $\mathrm{He}$ was interested in the xerophytic properties of the plants characteristic of this relatively high rainfall area. In 1932 his Presidential Address to the Linnean Society of New South Wales was on The Plant in Relation to Water, with special reference to the properties of xerophytes. Later Osborn's interest in ecology was associated with starting others on ecological descriptions of parts of New South Wales. In that period he published a paper jointly with Robertson on the ecology of the Myall Lakes vegetation.

Osborn became Sherardian Professor of Botany and a Fellow of Magdalen College, Oxford, in 1937. The Oxford Department was very poorly housed in cramped surroundings in an old building in the Oxford Botanic Garden. The Botanic Garden at Oxford, founded in 1621 , had become somewhat neglected but Osborn stimulated collaborative work with the garden, and this continued strongly even after the department, due to Osborn's initiative, moved to the new laboratories. As Nature said at the time, "the great improvements in the gardens, which have occurred in recent years, owe much to his expert supervision and advice". The achievement of causing a new laboratory to be built was an important contribution, particularly in the difficult period for planning and constructing buildings in the war and immediate post war years. At the same time Osborn spent much time on university business, and was in demand for advisory work for the Agricultural Research Council, of which he was a member (1945-49), and other public bodies.

In 1953 Osborn retired from the Chair at Oxford and returned to Australia. After a short period of residence in Melbourne he returned to Adelaide to live and became Deputy Master of St Mark's College, of which he had been one of the founders. He gave some courses in the Adelaide Botany Department and regularly attended the departmental seminars. Many younger members of staff and students appreciated conversation with this veteran of three different universities; he had the distinction of being Professor Emeritus of both Oxford and Adelaide Universities. In 1960 Osborn married Marjorie Sabine and they both contributed to the social life of the Adelaide Botany Department.

Osborn was a good lecturer and teacher who succeeded in attracting students of quality; they valued the association with a man who attempted to give them an understanding of high standards of science. Former Australian students include J. G. Wood (formerly Professor of Botany, Adelaide), N. A. Burges (Vice-Chancellor, University of Northern Ireland), M. R. Jacobs (formerly Director General of Forestry), D. Martin (Officer in Charge, Tasmanian Regional Laboratory, CSIRO), H. K. C. Mair (Director and Chief Botanist, National Herbarium, Sydney), Sir Rutherford Robertson (Head, Research School of Biological Sciences, Australian National University), Lilian Fraser (Chief Biologist, Division of Science Services, NSW Department of Agriculture), Joyce Vickery (formerly Botanist, NSW Department of Agriculture), N. C. W. Beadle (Professor of Botany, University of New England) and Gwenda Davis (Associate Professor of Botany, University of New England).

\section{Announcements}

\section{International Meetings}

August 27-September 1, Eighth Leucocyte Culture Conference. (Professor Kerstin Lindahl-Kiessling, University of Uppsala, The Institute for Medical Genetics, V. Agatan 24, S-75220 Uppsala, Sweden.)

August 31-September 1, The European Symposium of the International Association of Forensic Toxicologists. (Faculty of Pharmaceutical Sciences, Dept. of Toxicology, State University of Gent, Hospitaalstraat 13, 9000 Gent, Belgium.)

September 2-7, First International Congress for Bacteriology. (Secretariat, 'Kenses', P.O. Box 16271, Tel Aviv, Israel.)

September 2-7, International Association of Microbiological Societies. (The Inter- 